\title{
Some results of a computerized comparative analysis of the Balto-Finnic runotunes
}

Melody types as phenomenal units of folk music constitute an essential aspect of research in folk music studies. All folklore phenomena, including melodies, disseminate as variants in space and time. A type is formed of a complex of its variants (samples) united by the basic qualities of content and form (Rüütel 1986).

The genetic ties of folk music appear first of all in the level of the melody types but it must be taken into consideration that, on the one hand, outwardly very similar melodies may derive in different locations independently; on the other hand, the melodies of common genesis may acquire different shapes above recognition while spreading in time and space. The establishment of typologically related tunefamilies requires a thorough typological research. The conclusions drawn from occasional examples can not give reliable results.

The differentiation of melody types, however, especially in archaic music, is rather complicated. It demands a very exact and detailed analysis and special methods. This is the reason why the problem of musical typology of folk melodies on international scale has not been solved yet. Several attempts have been made, based on different material and different methods. Let us remind here Finnish researchers I. Krohn and A. Launis, Hungarians Z. Kodály, P. Járdányi etc., Swedish system by J. Ling and M. Jersild, computerized experiments by A. Elschekova, the so called Wroclaw taxonomy by A. Czekanowska, and very interesting results which have been gained by R. Pelinski on the tunes of the Eskimo personal songs (see, e.g. Bartók \& Kodály 1997, Járdányi 1964, Launis 1910, Launis 1930, Járdanyi 1964, Ling and Jersild 1965, Elschekova 1966, Czekanowska 1977, Pelinski 1981). Still, universal methods suitable for all musical cultures have not been created. Maybe it is eventually impossible, as different musical cultures are so diverse.

The original computerized method for distinguishing melody types, worked out at the Folklore Department of the Institute of Estonian Language, is based on modelling the melody on the basis of the melodic context (see: Rüütel 1979; Rüütel 1981; Rüütel 1986; Rüütel 1986b; Rüütel \& Haugas 1990). It enables to distinguish typologically related melody groups as well as to discover their possible relations and overlaps.

The most efficient way for solving these problems appeared to be the cluster analysis method, which permitted to group tunes under study round fixed centres (melody models). Such grouping (clusterization) corresponds to the dialectic 
notions of "type" and "variant" in the folklore theory according to which all variants of a folklore (or folk music) phenomenon (type) share the common basic form, from which they may differ in detail, having at that a common invariant (see, e.g. Rüütel 1986).

Special studies have shown that such an invariant of old Estonian runo-tunes is expressed by the system of basic tones of a melody (by its most stable elements) represented by the dominating pitch value of the most stable syntactical positions of melodies of a given typological group (Rüütel 1980).
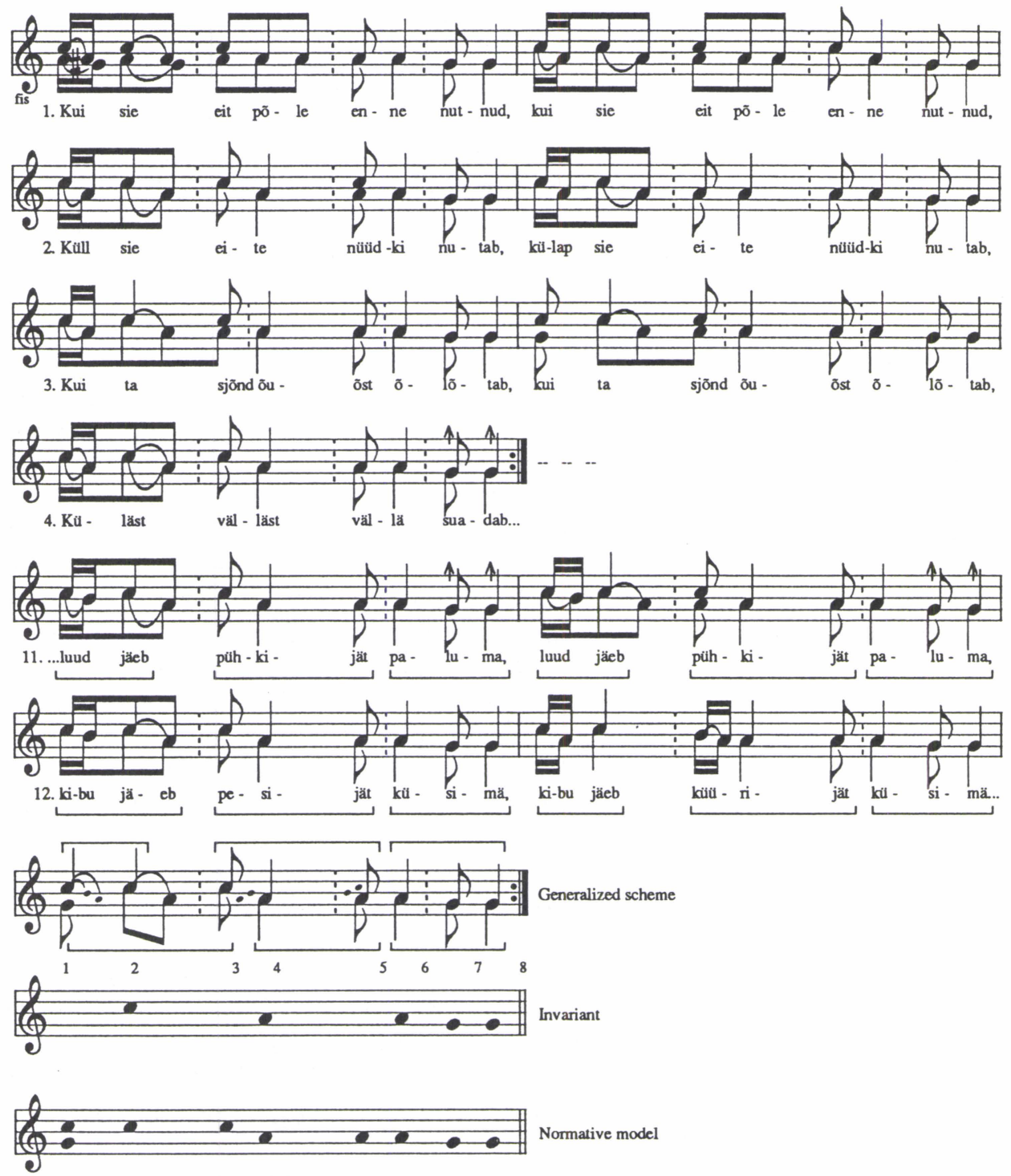

Example 1. Wedding song from the island Kihnu. TRÜ, EKRK, Fon. 1,3. (E. Laugaste \& H. Pedusaar 1958.) 
Such an invariant reveals itself only after the analysis of tune samples of an established melody type and contains the pitch values of only a part of syntactic positions of a melody (the most stable ones).

In addition to the invariant, every melody type is also characterised by a certain basic form - the normative model - which is formed on the basis of the most probable (most often appearing) value (pitch degree) of every syntactic position of the melodies in the given typological group (see Example 1).

Mathematically, the normative model is the mode of the multidimensional distribution of melodies of a given melody group. Such normative models (centres) can be found with the help of a statistic analysis of the melodic context before establishing typological groups of tunes under the study. Such models may be represented by the concrete melody specimen but in some cases they appear only as an abstraction (see, e.g. Rüütel 1981).

We have worked out an iterative algorithm ("Centre") for the preliminary establishment of the initial centres of classification (Rüütel, Haugas 1990). It enables to create melody models, which serve as the basic forms of certain melody types.

Table 1.

\begin{tabular}{|r|r|r|r|r|r|r|r|r|}
\hline & \multicolumn{7}{|c|}{ The 1st Iteration } \\
\hline scale step & 1 & 2 & 3 & 4 & 5 & 6 & 7 & 8 \\
\hline 6 & 0 & 0 & 1 & 0 & 0 & 0 & 0 & 0 \\
5 & 4 & 4 & 3 & 1 & 5 & 1 & 0 & 0 \\
4 & 51 & 49 & 51 & 55 & 20 & 1 & 0 & 0 \\
3 & 11 & 35 & 36 & 39 & 43 & 9 & 3 & 2 \\
2 & 17 & 15 & 21 & 24 & 46 & 76 & 13 & 2 \\
0 & 44 & 12 & 15 & 11 & 17 & 35 & 98 & 125 \\
- & 4 & 16 & 4 & 1 & 0 & 9 & 17 & 2 \\
\hline aste & 1 & 2 & 3 & 4 & 5 & 6 & 7 & 8 \\
\hline 6 & 0 & 0 & 1 & 0 & 0 & 0 & 0 & 0 \\
5 & 3 & 4 & 3 & 1 & 5 & 1 & 0 & 0 \\
4 & 51 & 49 & 48 & 52 & 18 & 0 & 0 & 0 \\
3 & 11 & 34 & 33 & 36 & 40 & 8 & 1 & 0 \\
2 & 17 & 14 & 21 & 24 & 45 & 73 & 12 & 0 \\
0 & 39 & 8 & 15 & 11 & 17 & 34 & 85 & 0 \\
- & 4 & 16 & 4 & 1 & 0 & 9 & 17 & 0 \\
\hline aste & 1 & 2 & 3 & 4 & 5 & 6 & 7 & 8 \\
\hline 6 & 0 & 0 & 0 & 0 & 0 & 0 & 0 & 0 \\
5 & 1 & 2 & 2 & 0 & 3 & 0 & 0 & 0 \\
4 & 51 & 45 & 46 & 47 & 15 & 0 & 0 & 0 \\
3 & 8 & 30 & 23 & 27 & 36 & 1 & 0 & 0 \\
2 & 14 & 10 & 18 & 15 & 32 & 66 & 0 & 0 \\
0 & 19 & 5 & 6 & 6 & 9 & 23 & 0 & 0 \\
- & 2 & 3 & 0 & 0 & 0 & 5 & 0 & 0 \\
\hline aste & 1 & 2 & 3 & 4 & 5 & 6 & 7 & 8 \\
\hline 6 & 0 & 0 & 0 & 0 & 0 & 0 & 0 & 0 \\
5 & 0 & 0 & 0 & 0 & 1 & 0 & 0 & 0 \\
4 & 43 & 33 & 41 & 37 & 13 & 0 & 0 & 0 \\
3 & -0 & 25 & 7 & 24 & 30 & 0 & 0 & 0 \\
2 & 11 & 6 & 16 & 4 & 22 & 0 & 0 & 0 \\
0 & 12 & 2 & 2 & 1 & 0 & 0 & 0 & 0 \\
- & 0 & 0 & 0 & 0 & 0 & 0 & 0 & 0 \\
\hline
\end{tabular}

\begin{tabular}{|c|c|c|c|c|c|c|c|c|}
\hline aste & 1 & 2 & 3 & 4 & 5 & 6 & $i$ & 8 \\
\hline 6 & 0 & 0 & 0 & 0 & 0 & 0 & 0 & 0 \\
\hline 5 & 0 & 0 & 0 & 0 & 1 & 0 & 0 & 0 \\
\hline 4 & 0 & 26 & 30 & 19 & 13 & 0 & 0 & 0 \\
\hline 3 & 0 & 16 & 0 & 22 & 16 & 0 & 0 & 0 \\
\hline 2 & 0 & 1 & 11 & 2 & 13 & 0 & 0 & 0 \\
\hline 0 & 0 & 0 & 2 & 0 & 0 & 0 & 0 & 0 \\
\hline- & 0 & 0 & 0 & 0 & 0 & 0 & 0 & 0 \\
\hline aste & 1 & 2 & 3 & 4 & 5 & 6 & 7 & 8 \\
\hline 6 & 0 & 0 & 0 & 0 & 0 & 0 & 0 & 0 \\
\hline 5 & 0 & 0 & 0 & 0 & 1 & 0 & 0 & 0 \\
\hline 4 & 0 & 24 & 0 & 19 & 2 & 0 & 0 & 8 \\
\hline 3 & 0 & 5 & 0 & 9 & 16 & 0 & 0 & 0 \\
\hline 2 & 0 & 1 & 0 & 2 & 11 & 0 & 0 & 0 \\
\hline 0 & 0 & 0 & 0 & 0 & 0 & 0 & 0 & 0 \\
\hline- & 0 & 0 & 0 & 0 & 0 & 0 & 0 & 0 \\
\hline aste & 1 & 2 & 3 & 4 & 5 & 6 & $\bar{i}$ & 8 \\
\hline 6 & 0 & 0 & 0 & 0 & 0 & 0 & 0 & 0 \\
\hline 5 & 0 & 0 & 0 & 0 & 0 & 0 & 0 & 0 \\
\hline 4 & 0 & 0 & 0 & 14 & 2 & 0 & 0 & 0 \\
\hline 3 & 0 & 0 & 0 & 9 & 16 & 0 & 0 & 0 \\
\hline 2 & 0 & 0 & 0 & 1 & 6 & 0 & 0 & 0 \\
\hline 0 & 0 & 0 & 0 & 0 & 0 & 0 & 0 & 0 \\
\hline- & 0 & 0 & 0 & 0 & 0 & 0 & 0 & 0 \\
\hline aste & 1 & 2 & 3 & 4 & 5 & 6 & 7 & 8 \\
\hline 6 & 0 & 0 & 0 & 0 & 0 & 0 & 0 & 0 \\
\hline 5 & 0 & 0 & 0 & 0 & 0 & 0 & 0 & 0 \\
\hline 4 & 0 & 0 & 0 & 8 & 0 & 0 & 0 & 0 \\
\hline 3 & 0 & 0 & 0 & 8 & 0 & 0 & 0 & 0 \\
\hline 2 & 0 & 0 & 0 & 0 & 0 & 0 & 0 & 0 \\
\hline 0 & 0 & 0 & 0 & 0 & 0 & 0 & 0 & 0 \\
\hline- & 0 & 0 & 0 & 0 & 0 & 0 & 0 & 0 \\
\hline & & & & 4 & & & & \\
\hline $\begin{array}{r}\text { model } \\
\text { (Order of }\end{array}$ & 4 & 4 & 4 & 3 & 3 & 2 & 0 & 0 \\
\hline appearance) & 4 & 6 & 5 & 8 & $i$ & 3 & 2 & 1 \\
\hline
\end{tabular}

The algorithm is based upon the gradual reduction of the objects dimension. Table 1 illustrates how it works on the real material. On the horizontal line are indicated 8 syntactical positions (syllable-notes) of one-line runo-tunes, in vertical - pitch degrees (here they are substituted by scale steps). Numbers in columns show the 
total frequency of occurrence of a given pitch degree (scale step) in all samples of the analysed melodies in a given position. The creation of models starts with the maximum value. Thus the 1st model has the basic tone in the 8th position. In the next step only melodies with the basic tone in the 8th position are selected and the next maximum will be marked in the corresponding position of the model (here it is also 0 in the 7th position). Then melodies with the two established features will be chosen and the next maximum will be found, etc. The process lasts until the values of all 8 positions of a model are found. The new iteration starts with the 2 nd maximum value of the initial data, etc. Another iterative algorithm ("Cluster") enables to compare all the tune samples with all the models (centres), to find out the model which any tune sample is the nearest to and classify all of them accordingly into clusters which in our case correspond to the typological groups of melodies.

The following prerequisites should be taken into account when developing a method of cluster analysis of the folk tunes:

1. Clusters (typological groups) differ greatly as to their volume, i.e. by the number of objects (melodies) in the cluster, since

a) different melody types are differently distributed in both space and time, and

b) different typological groups are not equally represented in the archives of folk tunes under study.

2. Clusters differ as to their homogeneity, i.e. different typological groups are characterised by different degrees of variability.

3. Clusters differ to their compactness, i.e. the borderline of a given cluster may be obscure and share several common points with the other clusters, since different typological groups may overlap and contamine; certain melodic types may vary in its spread even so greatly that quantitative changes turn into qualitative ones and a part of melody variants of the primary group may develop into a new type with an essentially different basic form.

The above mentioned traits are universal, they characterise the typology of folk music and folklore in general.

While choosing the method, one should also bear in mind the concrete research object, i.e. the Estonian runo song tunes. The special peculiarities of the Estonian runo songs are the following:

1. Dominant are syllable-notes, elaborate melismatic runo tunes are absent. Thus, the syllable-note may be taken for the basic unit of the melody-line. Possible deviations from the rule do not affect basically the results of the classification.

2. The melodies are built up on an equal number of elements of micro structure (melodic line) the invariant of which consists of eight syllable-notes. There occur one-line, two-line and more complicated structures with or without a refrain. The basic method is that of comparing melodies of equal length. The elaborated method enables also to compare melodies of different length (e.g. one-line and two-line tunes) but only those with an equal number of basic units. 3 . In establishing melody types the concrete pitches are of no essential importance, i.e. not the concrete scale but its relative degrees are significant, 
since the concrete scale degrees may vary in variants of one and the same melody types, as well as within one and the same song during the repetition of the line(s) (Rüütel 1980; Rüütel 1986b). Thus, while coding melodies, semitones are to be replaced by the steps of a respective scale and the scales should be studied separately after the typological groups have been fixed.

4. Often melodies are polyfunctional, i.e. they are used in several song genres. Therefore it is reasonable not to restrict the selection of the material to one genre or another, and not to consider the genre as one of the parameters in melody grouping (as it was done, e.g. in the so-called Wroclaw taxonomy, where genre is one of the basic attributes of the items of the taxonomy - see Czekanowska 1970).

5. The situation is similar with the rhythmic patterns which are relatively independent and enter into various relations with the melody types (see Rüütel 1986b).

Correlation of the melody types with the other musical or non-musical features (e.g., song genre, region, scale, rhythmic pattern, etc.) may be calculated only after the separation of the typological groups of melodies.

The quality of clusterization depends also greatly on the appropriate metrics (an objective procedure of measuring similarity, based on certain general indicator). Preliminary clusterizations based upon Euclidian metrics, or metrics of absolute values or the so-called supremum-norm did not give satisfactory results. It proved that in the Estonian runo-tunes the most important parameter is the quantity of melody elements corresponding (or not corresponding) to a certain normative model, not so much the qualitative difference of them. In other words, it is important how many elements of the melody differ from the normative model (centre), and not so much by how many semitones (degrees) they differ.

Still, the developed algorithm makes it possible, after the preliminary classification of tunes, to transfer the classification considering the stability of separate positions, as the deviations of the melodies from the most stable positions are much more significant than the deviations from the more variable ones.

Our study has proved that the clusterization process, not considering the weight of separate positions, makes it possible to obtain more "pure" melody types, i.e. more compact clusters. In another case, several tunes placed formerly on the borderlines of different clusters settled among the established clusters and it resulted the increase of the heterogeneity of the latter. Depending on the tasks and aims of the research, one can use both possibilities, e.g., at first, establish more pure types and then the expanded groups.

Theoretically it is possible, after the preliminary clusterization, to consider not only the weight of different syntactic positions, but also the weight of occurrence if a given scale degree in a given position. It was done in one of the earlier variants of our method (made by hand on a small amount of material) and such a manipulation gave extremely good results. But in the present algorithm of taxonomy it has not been realised yet, as it demands a special statistical analysis of tunes of all the established typological groups separately. 
The algorithm of clusterization is presented in: Rüütel, Haugas 1990. Before starting the computerised analysis it is necessary to define some parameters beforehand:

$\mathrm{Qr}$ - the maximum allowed distance of the objects from the centre of the cluster (radius of the cluster);

$\mathrm{Ql}$ - the maximum allowed distance between the centres in cluster connection; Qs - maximum allowed quantity of positions in the normative model with the diverse pitch values. In case $\mathrm{Qs}$ is surpassed, the cluster is split;

Qn - minimum allowed number of objects in the cluster. In case there are less objects in the cluster than Qn, the cluster is liquidated;

$\mathrm{Qw}$ - the parameter of use of weight coefficients.

The fixation of the last ones needs thorough empirical study and tests before getting satisfactory results.

After the first classification too small clusters (e.g., containing one or two tunes) are liquidated, the centres are checked up on the concrete tune material and corrected (if it is needed), then the new, more specified clusterization is carried out, centres are corrected again, etc. Further, the distance matrix for the centres is calculated, too close ones (e.g., differing in one or two elements only) are joined and the process of clusterization starts again. Such an iterative analysis lasts until the system becomes stable. Finally, most of the tunes usually appear to belong to certain clusters, part of the tunes remain on the borders of two or more clusters and part of them do not belong to any of them.

The above described method was used for studying the Estonian, Karelian and Ingrian one-line refrainless melodies, the one- and two-line melodies of the North Estonian parishes Jõhvi and Iisaku (see Tuvi 1992), etc. The investigated tune materials differed from each other both in degree of homogeneity and in volume. The results of a typological analysis based upon the one-line Estonian runo-tunes will be presented below in more detail.

While using the algorithm based upon the equal weight of different positions, melody samples from 830 Estonian one-line runo song tunes were distributed into 40 clusters (their models are presented below; tunes of the island Kihnu where the old folk songs are still in use are not included here). 
Table 2. Types of Estonian one-line runo-song tunes.

I

1: 03323200

4: 44433200

2: 03234200

17: 24534200

V

32: 04323320

33: 33543320

27: 03530432

8: 02430320

36: 03420220

7: 03030202

22: $0300-200$

18: 0032020
II

5: 02342200

31: 23422200

6: 43432202

34: 32332202

26: 43433223

25: 4443 2-03
III

29: 00332000

9: 02022000

30: 32432000

35: 33202000

(38:) 30304220

3: 32320000

28: 44340000

40: 34203000

37: 30200200

10: 23420032

(39:) 02322022

21: 23020000

Out of system:

11: $034320-0$

12: $0-0300-0$

19: 45240302

13: $0-002--0$

20: $4302-022$

14: $22002-00$

23: $520-0056$

15: - $-322-00$

16: $23320-02$

${ }^{1}$ Models are presented in scale steps:

0 - the fundamental tone

2 - the $2^{\text {nd }}$ scale step (the major or minor second higher than 0 )

3 - the $3^{\text {rd }}$ scale step ( the major or minor third higher than 0 ), etc.

- - a variable tone below the fundamental tone

178 tunes remained on the borders of two or more groups and only 29 did not belong to any group.

A distance matrix of the established tune groups models reveals the relations between separate centres and enables to discover interrelations of the whole typological system. 
Table 3. Typological system of the Estonian one-line runo song tunes (models, which differ not more than in three positions are joined by a steady line).

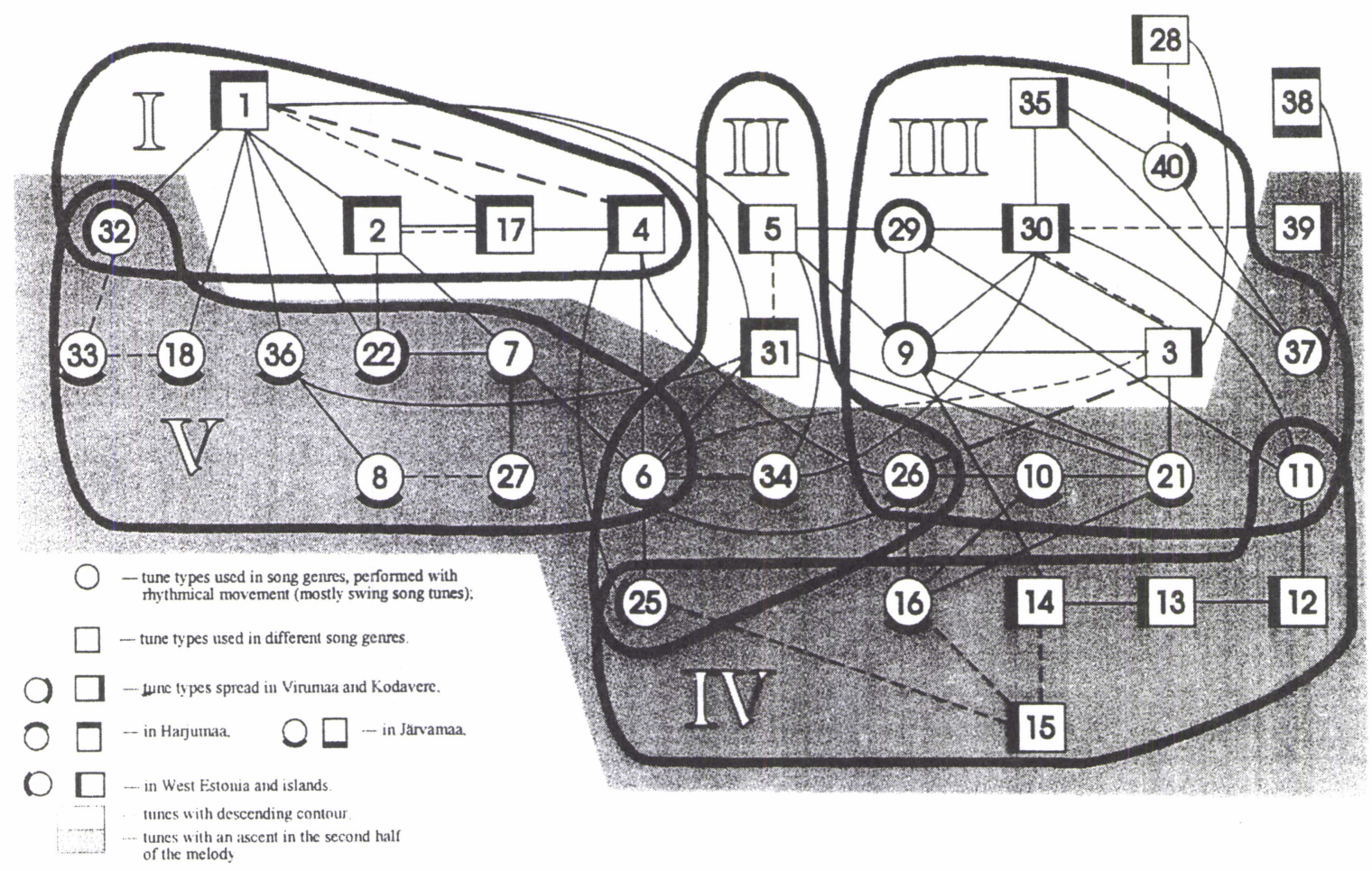

Besides, distances of interval relations were calculated which reveal the relations of models on the basis of the pure melody movement, independent from the position of the fundamental tone. Such a manipulation helps to discover tunes with similar melody lines (or their fragments) based upon scales with different positions of the tonic. (in Table 3 interrupted lines mark such kind of relations).

The discovered tune types could be distributed in five interrelated groups. Some types remain out of the system.

The correlation analysis of tune types and other features revealed that the established types are associated first of all with geographic regions, less with particular song-genres. It is caused by the fact that most of the tunes served as general tunes for different song-genres. Yet, it appeared that a part of melody types are characterised by clearly distinguishable genre peculiarities.

A part of tunes have a descending melody-movement (with a possible ascent at the beginning of the melody) and are based upon the speech-intonation (the upper part of the figure represented on the white background). Here belong first of all poly-functional tunes used in different genres.

Another part of tunes (represented on the black background) have a descendingascending contour which belong mostly to the swing-songs (primarily women's calendar-ritual songs sung while swinging, later also lyrical or narrative womenâs 
song sung while swinging). Here belong also some game songs melodies and exclusively some West Estonian wedding tunes (models 12, 13 and 15 in the IV the group).

In the mentioned speech-like melodies as well as in the prosodic intonation of the Estonian language melodic ascents usually coincide with the stressed syllables of the words and descents coincide with the non-stressed ones (exceptions from such regularity may mostly take place at the very beginning of a melody line). The pitch culmination of a melody corresponds to the prosodic culmination of a phrase (a verse). These melodies may be interpreted as generalised models of the speechintonation formed as a musical abstraction of the prosodic intonation of the 8syllable runoverse (see: Rüütel 1986: 173-180).

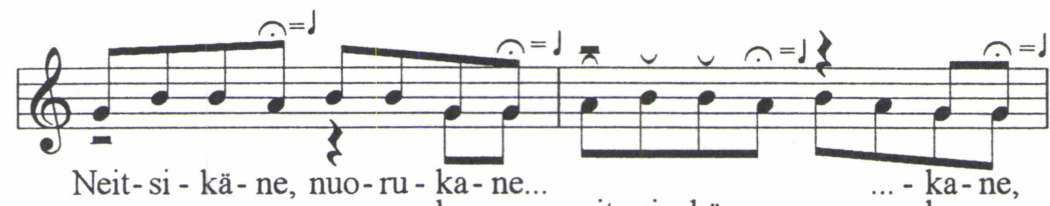

... - ka-ne, neit-si-kä-ne, nuo-ru-ka-ne...
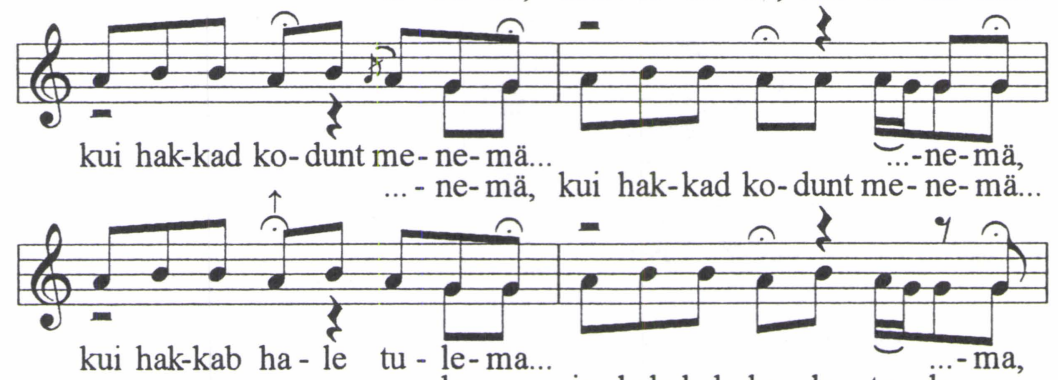

... - le-ma ja hak-kab ha-le tu- le-ma..

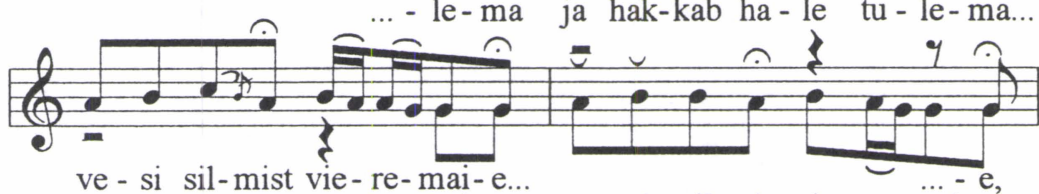

...-mai-e, ve-si sil-mist vie-re-mai-e...

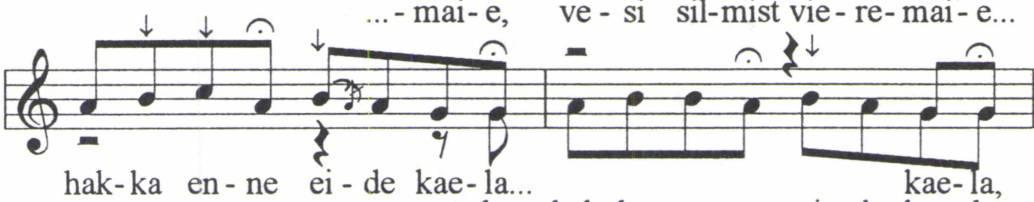

- la, hak-ka en-ne ei-de kae-la.

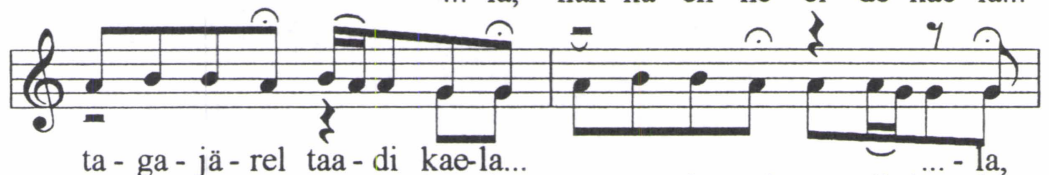

...kae-la, ta-ga-jä-rel taa-di kae-la..

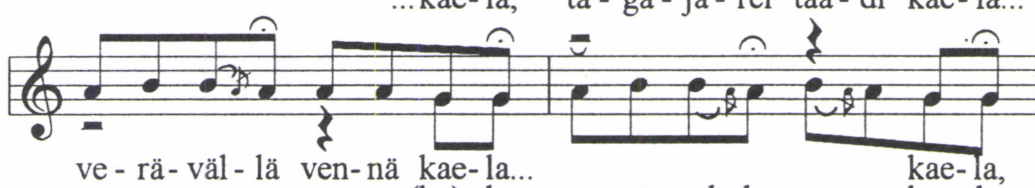

... (ka)ela, ve - rä-väl- lä ven-nä kae-la... 


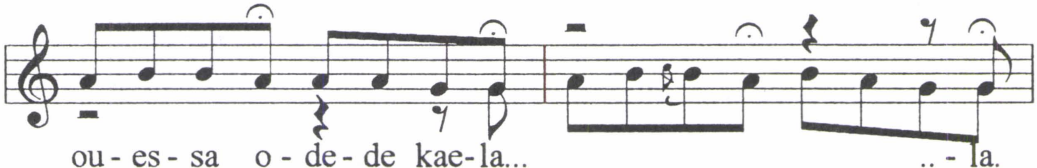

ou - es - sa o-de-de kae-la...

...-la, ou-es-sa o-de-de kae-la.

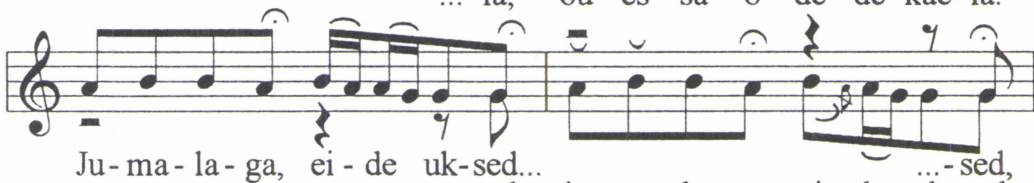

-sed, ju-ma-la-ga, ei-de uk-sed..

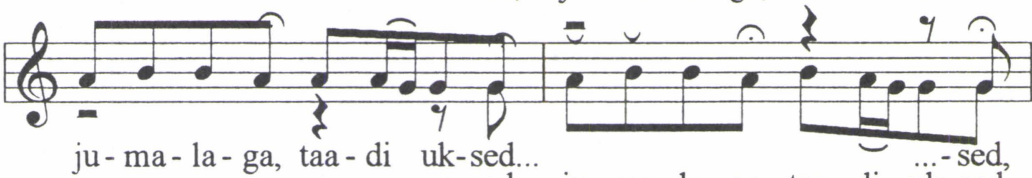

-.sed, ju-ma-la-ga, taa-di uk-sed..

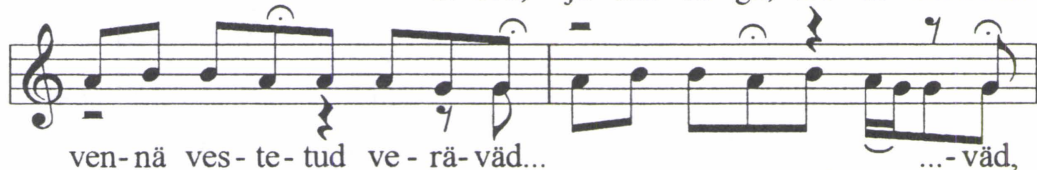

...-väd, ven-nä ves-te-tud ve-rä-väd..
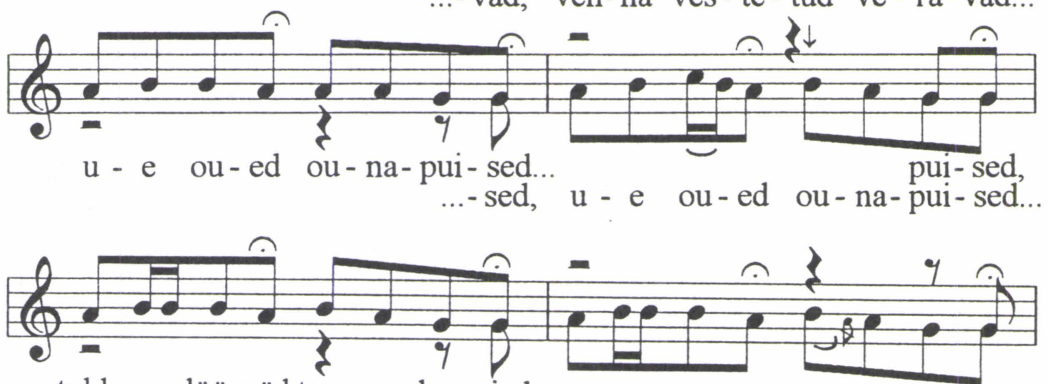

tuld a ga lüö-väd tum-ma kap-jad... _.. - jad ..-jad, tuld aga lüö-väd tum-ma kap-jad..

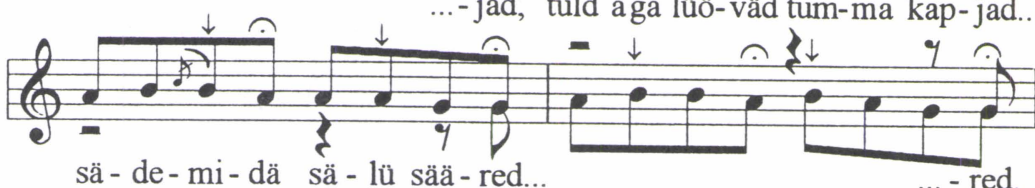

sä - de-mi- dä sä- lü sää-red...

... - red, sä-de-mi-dä sä- lü sää-red..

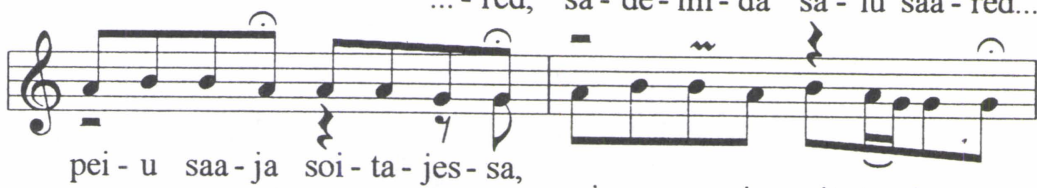

...-sa, pei-u saa-ja soit-ta-jes-sa.

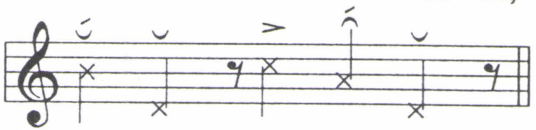

Ois - sa, hop - ois - sa!

Example 2. Wedding song from the Kuusalu parish. ERA, PO. 86B1. H. Tampere 1938. 
Such tunes were mostly used in different song-genres which were chanted or recited and whose rhythm was not subordinated to an accompanying movement. They were emotionally neutral and suitable for all songs which were recited as spells, charms, for communicating tidings, requests, edification, commands or simply as talk, narrative, etc. Such melodies were more closely connected with the structure of the text than its content. Due to the variability of the ancient tunes they could easily be adapted to different performing situations, concrete texts and rhythms (within the form of 8 metrical units). It often appeared that a singer actually had only one melody for most of her songs. Yet, statistical analysis of the tune-layer under discussion revealed the preference of older song genres, such as wedding songs, ancient epic songs, calendar-ritual songs, etc.

In the Estonian one-line runotunes the next rhythmic patterns are most common:

Table 4. Rhythmic patterns of the North Estonian runotunes.

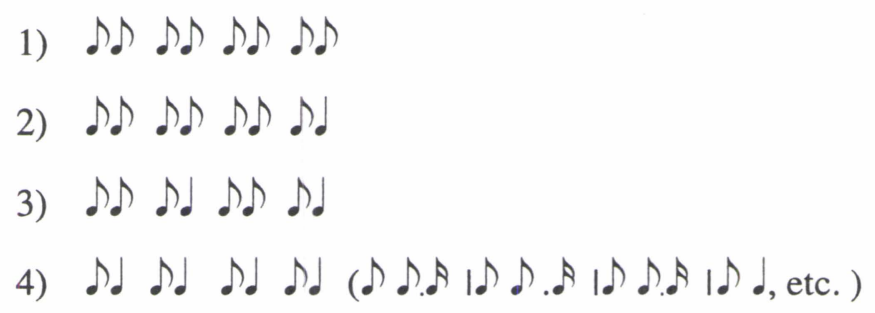

In speech-like poly-functional melodies rhythmic patterns 1,2 and 3 are most common. In eastern part of the dissemination area also the fourth pattern may occur. In all the presented patterns the metrical division may be changed during a song in accordance with the word stresses which are situated on the 1st syllable in Estonian and other Balto-Finnic languages (see tune examples 1 and 2) and the real duration of separate notes depends noticeably on the length of the syllables.

Swing-song tunes are characterised mostly by different modifications of the 4th rhythmic pattern and a fixed metre. Due to the special way of performing (singing while swaying on a big swing) and because the songs tried to correlate with the rhythm of swinging, the swing song melodies developed in a special way. Each uneven syllable note was stressed while coinciding with the moment of the kinetic accent increasing the speed of the swing. The prolongation of descent of each metrical foot (i.e. each even syllable-note) was dependent of the length and time of the movement curve of the swing (a descent and a new ascent). These prolonged notes were accompanied by melodic figurations as well as modifications in the melody contour (ascending motif, phrase and line endings) which contradict with the speech-intonation. 


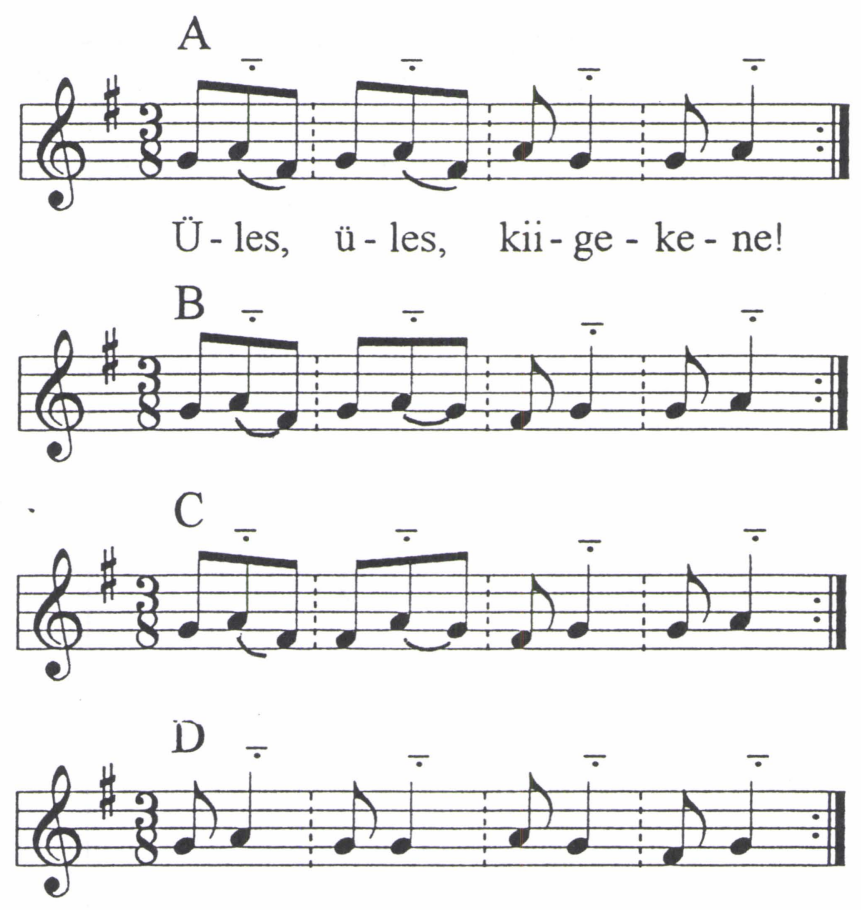

Example 3. Swing song. EÜS VII 2168 (190) Väike-Maarja.

Different types of the speech-like melodies were rather similar in their inner structure. The distribution of speech-like tunes expands from the northeast of Estonia to the southwest Estonian coast and the western Estonian islands (see also Tampere 1956; Tampere 1960). In South Estonia they occur rather sporadically mainly in peripheral areas (in Setu they occur only in lullabies and children amusement songs). 


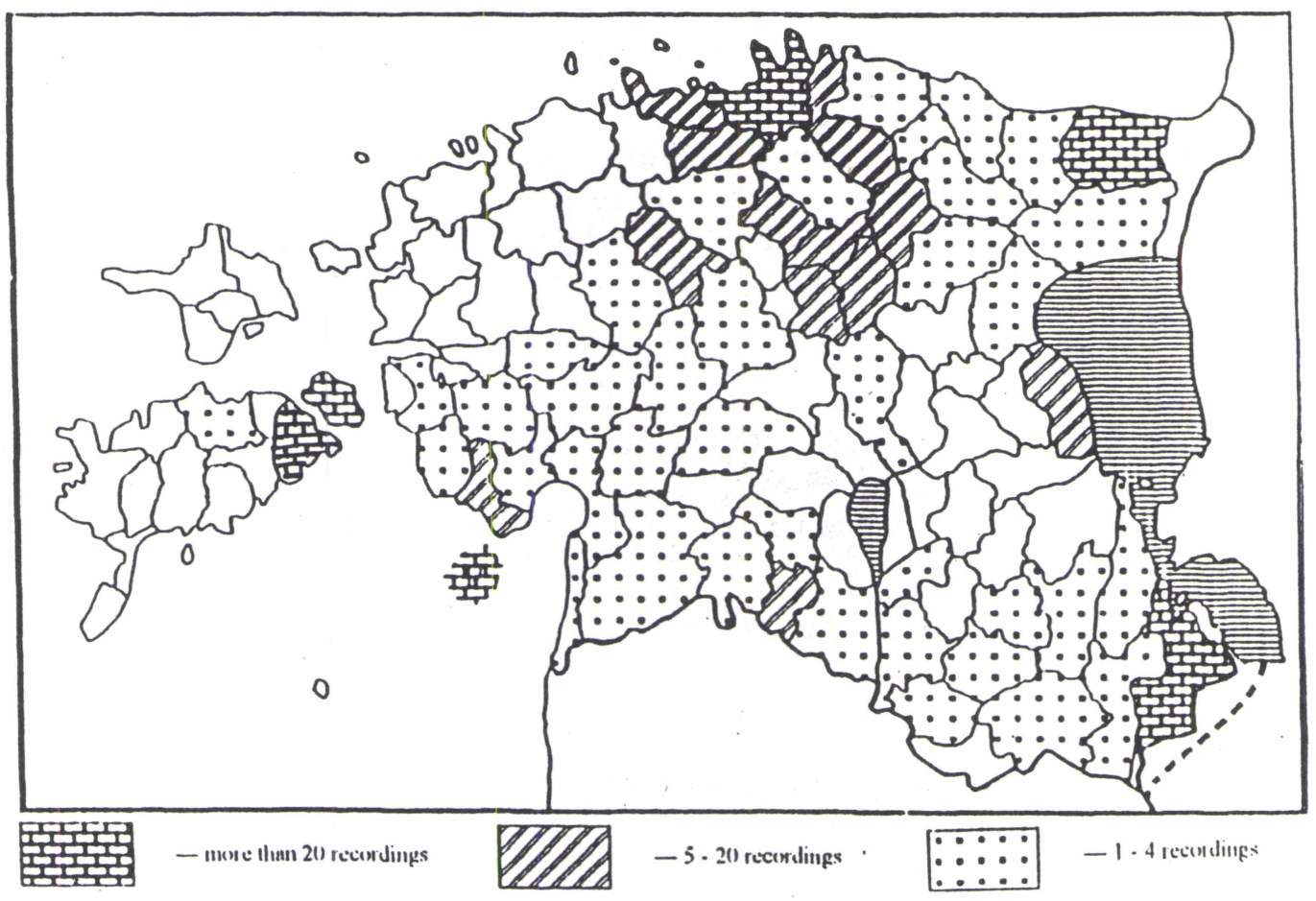

Map 1. One-line tunes of speech intonation.

The majority of tune types are spread in one, two or three neighbouring counties. Common distribution area of certain tune types joins the Northern Estonian coast with the Western Estonian coast and islands. Less often a tune type is spread all over Estonia. In the latter case we are merely dealing with a more general peripheral distribution. E.g. samples of the type 29 can be found in all the main distribution areas of the tune-layer under discussion. To this group belong in general a considerable amount of lullabies.

The swing-song tunes share a considerably richer spectrum of means of expression, which become observable on the level of both the typological and stylistic diversity (e.g., they contain an extreme variety of melismas, which are not characteristic of the runosongs in general, see Tampere 1960; Toi 1982). At that, the distribution area of special swing song tunes was noticeably narrower than that of the speech-like tunes being restricted with Järvamaa and the adjacent parishes of Harjumaa and Virumaa.

I have implied the same method of establishing tune types on the material of the Ingrian and Karelian one-line runotunes. Unfortunately I did not have in my disposal such an amount of material as the case with the Estonian tunes. I used the tunes published by Armas Launis in his "Ingrian runotunes" and "Karelian runotunes" (see Launis 1910; Launis 1930). These publications do not give the data about song genres (the melodies are published without texts) but the established 
tune types revealed noticeable correlation with the rhythmic patterns and topographical regions.

As the fixation of the fundamental tone in many cases is problematic, we made an experiment of using different variants of coding. In the Karelian materia, a part of the tunes which were coded in two variants appeared to be classified into separate groups and the distance matrix calculated on the basis of the interval relations brought these groups together. Thus, 4 from the established 14 groups appeared to coincide with some other groups and might be liquidated. A part of such variants remained out of the system.

The established tune types revealed noticeable correlation with the rhythmic patterns and topographical regions.

Table 5. Karelian one-line tune models and rhythmic patterns

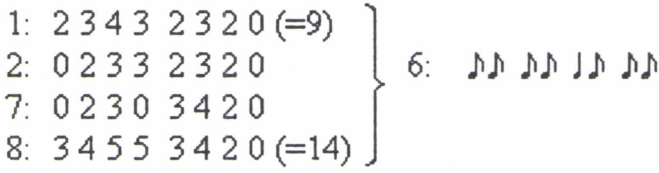

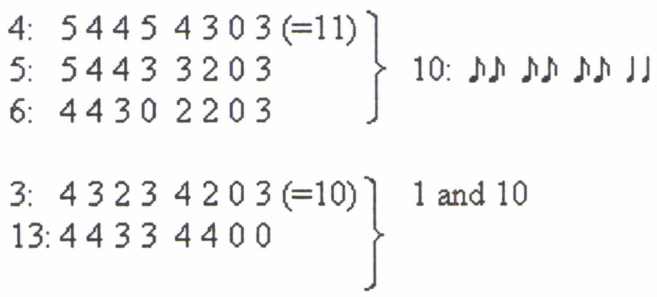

12: 44243020

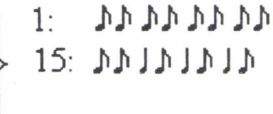


Table 6. Example of the Karelian clusters (models in scale steps, tune samples in semitones)

\begin{tabular}{|c|c|c|c|}
\hline \multicolumn{4}{|c|}{ 4: 54454303} \\
\hline 352,0 : & $055353 / 203$ & 10 & Sakkula \\
\hline $511,1:$ & $55 / 7525303 / 2$ & 10 & Sakkula \\
\hline 557,1 & $757553 / 203$ & 10 & Sakkula \\
\hline 536,1 & 73555303 & 10 & Vuole \\
\hline 537,1 & $755753 / 203$ & 10 & Vuole \\
\hline 562,1 & $77775302 / 3$ & 10 & Kattila \\
\hline & : 02303420 & & \\
\hline 70,0 & $02404 / 7 / 5420$ & 6 & Vuonninen \\
\hline 78,0 & $02404 / 7 / 5420$ & 6 & Vuonninen \\
\hline 73,0 & 024 0/2[0] 4/7 520 & 6 & Korpivaara \\
\hline 77,0 & $0244 / 04 / 752[4 / 2] 0$ & 6 & Korpivaara \\
\hline 91,0 & $02303 / 7[3 / 5] 5 / 320$ & 6 & Kivijärvi \\
\hline 92,0 & $02303 / 77 / 53 / 20$ & 6 & Kivijärvi \\
\hline 108,0 & $325 / 30 / 2[3 / 2] 3 / 755 / 3[3 / 2] 0$ & 6 & Kuivarvi \\
\hline 346,0 & 05454525 & 6 & Sakkula \\
\hline 75,0 & $024040 / 420$ & 6 & $?$ \\
\hline 76,0 & $024040 / 420$ & 6 & $?$ \\
\hline
\end{tabular}

In Ingrian material the situation was somewhat different. A great part of the tune samples with double coding remained out of the system and a part of their variants were distributed into different groups which contained other melodies as well. Correlation of tune types with the rhythmic patterns and topographical regions appear here also. Still, both the Karelian and the Ingrian material need more detailed analysis in the future.

The distance matrixes of the Estonian models with the Karelian and Ingrian ones based upon the scale step relations (considering the models that do not differ more than in three positions) revealed that the similarity of the Estonian one-line tunes with the Karelian ones was noticeably greater than that with the Ingrian ones.

$50 \%$ of the models of Estonian one-line tunes have Karelian parallels and $85 \%$ of Karelian models have Estonian parallels. 30\% of Estonian models have Ingrian parallels and $33 \%$ of the Ingrian ones have Estonian parallels.

$50 \%$ of Karelian models have Ingrian parallels but only $27 \%$ of the Ingrian ones have Karelian parallels.

Below only the closest parallels of Estonian, Ingrian and Karelian tune types are presented (differing in one or two positions). 
Table 7. Estonian and Ingrian parallels.
E 31: 23422200
E 2:03234200
E 11:034320-0
$110: 23+23200$
$1|1| 1 \mid$
$|1| 1 \mid$
I 19: $0+33+200$
126: $23+32020$
E 1:03323200
E 17: 24534200
11:32323200
E 14:22002-00
E $3: 32320000$
E 9: 02022000
$11111 \mid 1$
I 13: 22320000
| $|1|||||$

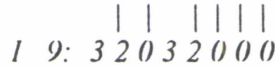
E 21:23020000

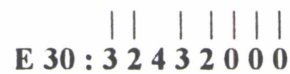
E 33: 33543320
I 3: 33203320
E $37: 30200200$
I21: $\begin{array}{ll}11 & 11 \\ 3020-202\end{array}$

Table 8. Estonian and Karelian parallels
E 2: 03234200
E 4: 44433200
E 8: 02430320
K $3:+323+203$
K 5: $5++33203$
K 2: 02332320

E 18: 0032020 -

K 9: $\begin{array}{llllll}0 & 1 & 1 & 1 & 1 & 1 \\ 0 & 2 & 2 & 0 & 2 & 0-\end{array}$ 
Table 9. Karelian and Ingrian parallels.
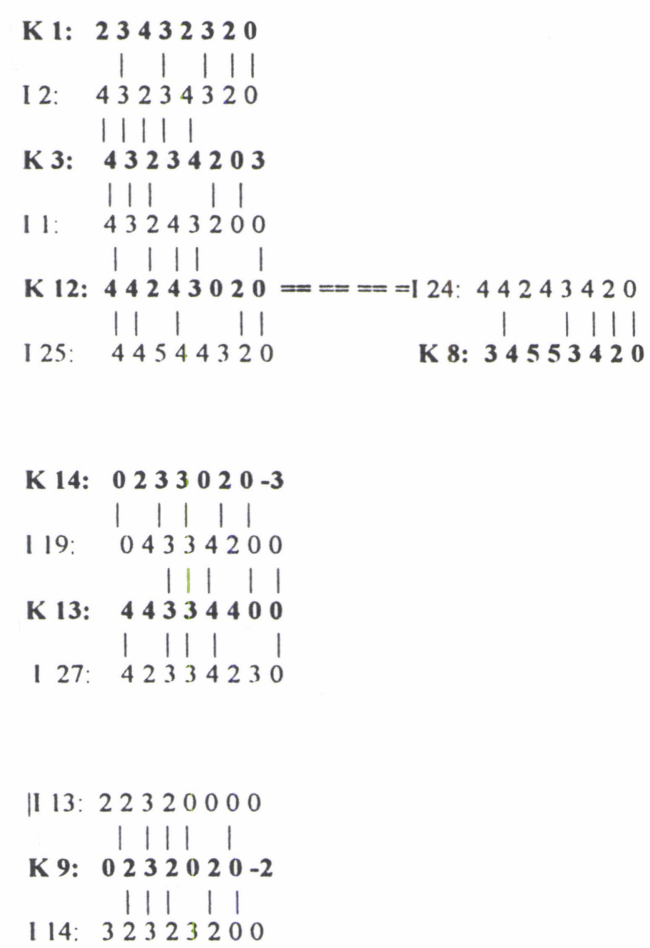

The discussed one-line speech-like melody layer which represents the most primitive and the most ancient runosong tune style was probably formed together with the runosong form (see Rüütel 1994).

Its main distribution area in northern and western Estonia coincides with the most probable area of the establishing of the runosong form in Estonia. Such melodies were spread also in Ingria, being especially characteristic of the Votians (the native population of this area) who were both culturally and linguistically very close to the northern Estonians. Parallels could be found also by Karelians (where, as by Estonians, in general the more recent style of two-line melodies prevail in runo-songs). The common melodic structure appears also in two-line Balto-Finnic runo-tunes which have probably preserved some relicts of the former one-line ones (Kolehmainen 1977; Rüütel 1986: 164, 183). The basic stylistic traits of this tunelayer - one-line form, diatonic scale with a narrow tonal range (a third or a fourth), descending melody contour, step-by-step melody movement based upon syllablenotes, etc. - are characteristic also to the melodies of the most ancient song genres of other Finno-Ugrians (see Rüütel 1986a; Rüütel 1977; Rüütel 1982; Rüütel, Remmel 1980 etc. ), including those who belong to the so called Volga-Ural pentatonic area which was formed probably later (Vargyas 1981). These traits characterise also the ancient vocal genres of the Estonians which were probably formed before the runosong (see Rüütel 1994; Salve, Sarv 1987; Sarv 1986; Pino, 
Sarv 1991; Pino, Sarv 1992).

The typological analysis enables to discover the inner relations of the melodic structure of folk music, based on objective parameters. Interpretation of stylistically and even typologically related melodies is still always problematic. It is difficult to decide whether we have to deal with genetic ties of the tune types, with pure typological similarity of melodies or with the common basis of the prosodic intonation and other linguistic characteristics appearing in songs of the peoples belonging to the same linguistic group.

\section{References}

Bartók, Béla \& Kodály, Zoltán 1997. A Magyar népzene tára X. Népdaltípusok 5, ed. Paksa Katalin. Corpus Musicae Popularis Hungaricae X. Akademia Scientarum Hungarica. Budapest. Balassi Kiadó.

Czekanowska, A. 1977. On the Theory and Definitions of Melodic Type. 1976 Yearbook of the IFMC. Vol 8.

Elschekova, A. 1966. Strukturelle Frühformen slavischer Volksmusik. - Anfange der slavischen Volksmusik. Bratislava.

Járdányi Pál 1964. Ungarische Volksliedtypen. Budapest.

Kolehmainen, I. 1977. Kalevalasävelmien musikologista syntaksia. Pro gradu tutkielma musiikkitieteessä ja sivulaudaturtyö suomalaisen ja vertailevan kansanrunouden tutkimuksessa. Helsinki.

Launis Armas 1910. Inkerin runosävelmät. Suomen kansan sävelmiä. Neljäs jakso: Runosävelmiä I. SKS Toimituksia. 68 osa. Helsinki.

Launis Armas 1930. Karjalan runosävelmät. Suomen kansan sävelmiä. Neljäs jakso: Runosävelmiä II. SKS Toimituksia 68. Helsinki.

Ling, J. \& Jersild, M. 1965. A Method of Cataloging Vocal Folk Music. A Description of the System Used at the Svenskt Visarkiv. Särtryck ur ARV Stockholm.

Pelinski, R.1981. La musique des Inuit du Caribou. Montreal.

Pino,V. \& Sarv,V. 1991. Setu surnuitkud I. Tallinn.

Pino,V. \& Sarv,V. 1992. Setu surnuitkud II. Tallinn.

Rüütel, I. 1970. Vadja rahvalauludest ja nende suhetest eesti laulutraditsiooniga. Läänemeresoomlaste rahvakultuurist. Tallinn.

Rüütel, I. 1977. Vadja rahvamuusika tüpoloogia ja stiilid. Soomeugri rahvaste muusikapärandist. Tallinn.

Rüütel 1979. Opyt strukturno-tipologicheskogo issledovanija odnostrochnyh runicheskih napevov. Preprint KKI-10.Tallinn.

Rüütel, I. 1980. Mustjala regiviiside tüpoloogia. Ars Musicae Popularis 1. Tallinn.

Rüütel, I. 1981. Typology of Estonian Runo-Tunes: Experiment and Some Results. Preprint KKI-18. Tallinn.

Rüütel, I. 1982. Oudekki Figurova vadja rahvaviisid. Läänemeresoomlaste etnokultuuri küsimusi. Tallinn. 
Rüütel, I. 1986. Tipologia, struktura i razvitie estonskih odnostrochnyh svadebnyh napevov. Muzyka v obrjadah i trudovoj dejatelnosti finno-ugrov, ed. I. Rüütel. Tallinn.

Rüütel, I. 1986a. Odnostrochnye uzkoobyemnye svadebnye napevy v obshchem kontekste estonskih runicheskih pesen. Muzyka $v$ svadebnom obrjade finnougorskih $i$ sosednih narodov, ed. I. Rüütel. Tallinn. (In Russian)

Rüütel, I. 1986b. Experiment in Folk Music Typology and Establishing Correlations Between Tune Types and Other Features. International Kodály Conference. Budapest 1982. Editio Musica. Budapest.

Rüütel, I. 1990. Die Schichten des Volkslieds der Setukesen und ihre ethnokulturellen Hintergründe. Finnisch-ugrischen Forschungen. Vol. XLIX.

Rüütel, I. 1994. Istoricheskie plasty estonskoj narodnoj pesni v kontekste etnicheskih otnoshenij. Ars Musicae Popularis 12. Tallinn.

Rüütel, I. \& Haugas, K. 1990. A Method for Distinguishing Melody Types and Establishing Typological Groups (on the Material of Estonian Runo Songs). Musikometrika 2. Quantitative Linguistics. Vol. 43, ed. M. G. Boroda. Universitätsverlag Dr. N. Brockmeyer. Bochum.

Rüütel, I. \& Remmel, M. 1980. Opyt notacii i issledovanija vepsskih prichitanij. Finno-ugorskij muzykalnyi folklor i vzaimosvjazi s sosednimi kulturami, ed. I. Rüütel. Tallinn.

Salve, K. \& Sarv, V. 1987. Setu lauludega muinasjutud. Tallinn.

Sarv,V. 1986. Vidy setuskih prichitanij i ih muzykalnye osobennosti. Muzyka $v$ obrjadah i trudovoj dejatelnosti finno-ugrov, ed. I. Rüütel. Tallinn.

Tampere, H. 1956. Eesti rahvalaule viisidega I. Tallinn.

Tampere, H. 1960. Eesti rahvalaule viisidega II. Tallinn.

Toi, R. 1982. Swing-Songs in Estonian Folk Songs. Folkloristica: Festschrift for Felix J. Oinas. Indiana University Uralic and Altaic Series, Volume 141. Bloomington. Indiana.

Tuvi, E. 1992. Kokamägi, H., Tuvi, E. Jõhvi ja lisaku kihelkonna regilauludest ja -viisidest. Ida-Virumaa rahvakultuurist, ed. I. Rüütel). Tallinn.

Vargyas, L. 1981. The First Phase of Development of Finno-Ugric Music. Congressus Quintus Internationalis Fenno-Ugristarum. Turku 20.27.8.1980. Pars VIII, Turku. 